\section{Effect of Scionwood Packing Moisture and Cut-end Sealing on Pecan Graft Success}

\author{
Monte L. Nesbitt, ${ }^{1}$ \\ William D. Goff, ${ }^{2}$ and \\ Larry A. Stein ${ }^{3}$
}

\begin{abstract}
Additional index words. Carya
illinoinensis, grafting, scion, scionwood, propagation
\end{abstract}

\begin{abstract}
Summary. Pecan (Carya illinoinensis) cultivars are commercially propagated by grafting and budding. The whip graft, bark graft and four-flap graft, the most frequently used techniques for pecan grafting, require dormant scions, collected and stored for 60 to 120 days before the spring grafting season. Poor graft success is sometimes attributed to poor handling and storage of the scionwood. Moisture content of packing material, sealing cut ends of the scions with wax, and use of polyethylene bags was evaluated in 1998 and 1999. Scions were collected in early February each year, and stored for 60 to 70 days in a household refrigerator at $2^{\circ} \mathrm{C}\left(35.6^{\circ} \mathrm{F}\right)$ under different treatment regimes. Scion viability was tested by bark grafting on limbs of mature pecan trees. Moisture of the scions was affected each year by the amount of water added to packing material and by sealing the cut ends, but the differences did not impact graft success. In 1998, graft success rate was equally good among scions stored in polyethylene bags with different amounts of added moisture, whether cut ends were sealed or not. Graft success in 1999 was affected by an interaction of sealing the cut ends, packing material and location of grafting.
\end{abstract}

${ }^{1}$ Research horticulturist, Alabama Agricultural Experiment Station, Gulf Coast Regional Research and Extension Center, 8300 State Hwy. 104, Fairhope, AL 36532 .

${ }^{2}$ Extension horticulturist and professor, Department of Horticulture, Auburn University, 21 Extension Hall, Auburn, AL 36849

${ }^{3}$ Extension horticulturist, Texas A\&M University Research and Extension Center, P.O. Box 1849, Uvalde, TX 78802 .
$\mathrm{P}$ ecan is heterozygous, producing diverse seedlings with highly variable nut production traits. The commercial pecan industry is dependent upon propagation by grafting and budding, because propagation by tissue culture or vegetative cuttings has not been perfected. The first pecan tree was successfully grafted in Louisiana, in 1846 or 1847 by a plantation slave named Antoine (Taylor, 1905). Since that time, grafting and budding techniques have been developed for pecan that give good success rates, including the whip graft, inlay bark graft, four-flap graft, and patch bud. In the pecan industry, a success rate of $75 \%$ or higher is considered good, when numerous trees are propagated at one time. Experienced pecan propagators seldom obtain $100 \%$ graft success, and occasionally have low success rates for no apparent reason, often attributing such results to environmental stress (e.g., drought, high temperature), or to unviable scionwood. Scion viability can be compromised in nature before removal from the source tree (e.g., freeze injury) or in cold storage, since dormant previous season buds are necessary for most pecan grafting methods.

Scionwood storage technology has evolved with the advent of affordable, electric-powered refrigeration and polyethylene-plastic films and bags. Before these technologies were available, dormant scions were either buried underground in bundles (Hartmann et al., 1990) or placed vertically in the ground in shady locations with the basal cut ends buried (Reed, 1926). Cold rooms, cellars, and basements were also used, wherein the scions were stored in open boxes, either uncovered coated in wax or covered by layers of hay or leaves in boxes (Morris, 1921; Mullenax, 1983). When refrigeration became commonly available, scionwood continued to be stored in wax-treated cardboard boxes filled with moistened sawdust or sphagnum peat. Polyethylene bags became available that allowed good gas exchange while preventing moisture loss and were suitable for small bundles of scionwood (Hartmann et al., 1990). Today, most pecan scionwood is wrapped in damp newspaper or packed in sphagnum or cedar shavings and stored in polyethylene bags. The amount of moisture added to each scionwood bundle varies widely among pecan growers, nurserymen, and scientists, and is often cited as a cause for loss of viability of the scions during cold storage.

The practice of sealing the cut ends of pecan scions before storage is a recommended practice in both old and new extension propagation bulletins (McEachern and Stein, 1997; Mullenax, 1983; Reed, 1926; Sauls and Crocker, 1979). The recommended sealants include paraffin, shellac, and special grafting waxes containing resin and beeswax. Sealing is done before cold storage, and may be done again after storage if scions are cut a second time before transport to the field (Sauls and Crocker, 1979). However, the practice is debated as to whether it improves moisture content of the scions, and whether that improved moisture content improves graft success rate. The objective of our study was to determine whether cut-end sealing and moist packing of scions in polyethylene bags affected graft success of pecan.

\section{Materials and methods}

Fully dormant pecan scions were cut in early February 1998 and 1999. The elapsed time from removal of the wood from the source tree to arrival in the laboratory was about $\mathrm{l} \mathrm{h}$. In the lab, previous season stems with good vigor and normal-appearing buds were cut into $20-\mathrm{cm}$ (8-inch) lengths, having at least two nodes. These scions ranged from 9 to $15 \mathrm{~mm}(0.35$ to 0.59 inches) in diameter.

In 1998 , there were 10 storage treatments in a $2 \times 5$ factorial design. Half of the cut scions were sealed on both cut ends with melted paraffin, and half were untreated. Five scions were then randomly chosen from the two cut-end sealing treatments, grouped into blocks by size to decrease variability in the total fresh weight of the five combined scions, and assigned to one of five packing material treatments. The five packing treatments were 1) no supplemental moisture, bagging, or packing material (control); 2) closed polyethylene bag [3.7-L (1-gal) size; $0.07 \mathrm{~mm}(2.7$ mil or 0.0027 inches) thick; Pactiv Corp., Lake Forest, Ill.]; 3) closed polyethylene bag with $50 \mathrm{~g}(1.8 \mathrm{oz})$ dry cedar shavings; 4) closed polyethylene bag with $50 \mathrm{~g}$ cedar shavings and $50 \mathrm{~mL}(1.7 \mathrm{fl} \mathrm{oz})$ distilled water; and 5 ) closed polyethylene bag with $50 \mathrm{~g}$ 
Table 1. Effect of cut-end sealing (CES) and five packing $(P)$ treatments on scion moisture and graft success in 1998. Grafting was done at Fairhope, Ala.

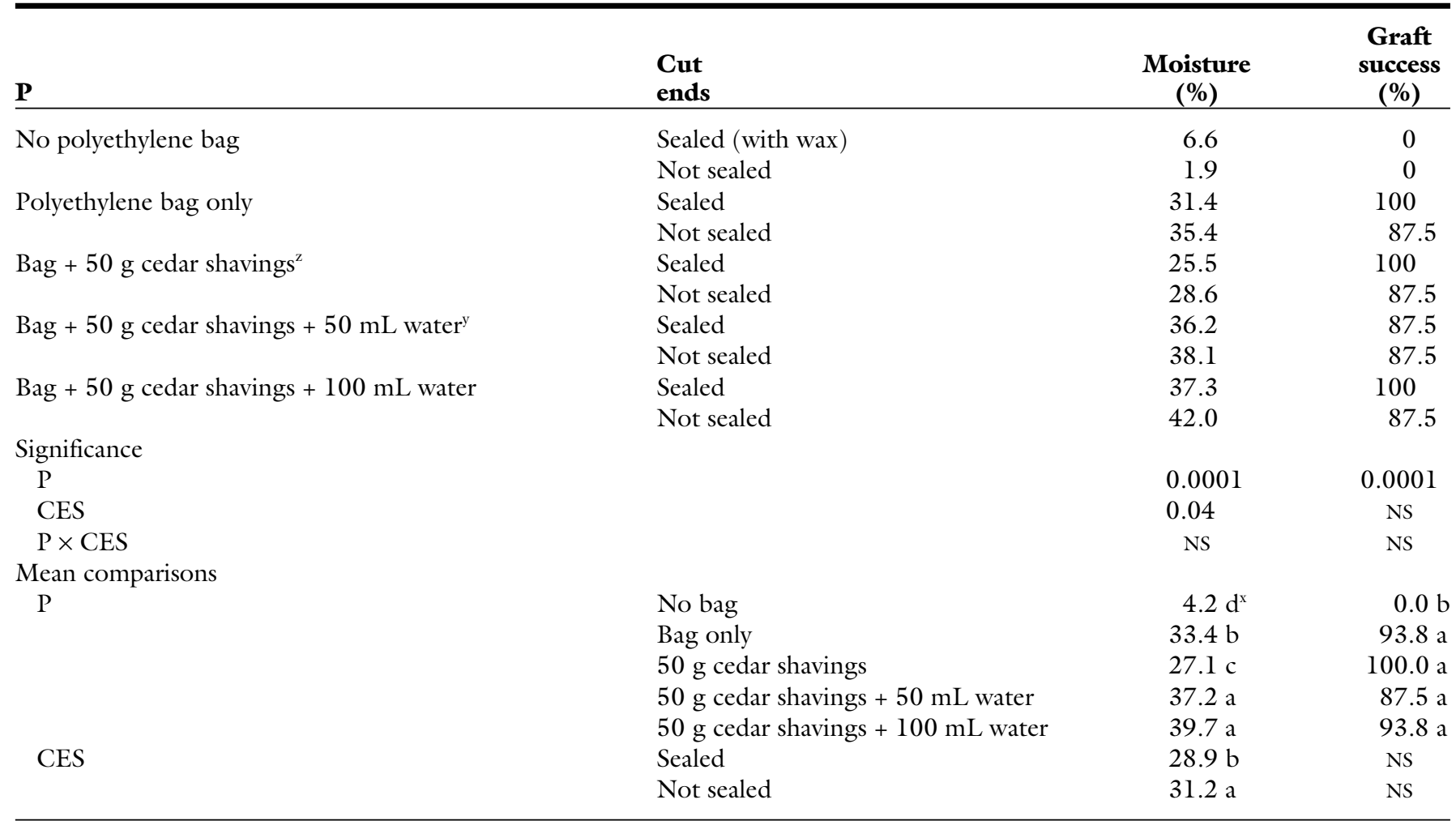

$\overline{\mathrm{z}} 50 \mathrm{~g}=1.8 \mathrm{oz}$.

y $50 \mathrm{~mL}=1.7 \mathrm{fl} \mathrm{oz} ; 100 \mathrm{~mL}=3.4 \mathrm{fl} \mathrm{oz}$

${ }^{x}$ Means within columns with the same letter are not significantly different, using Duncan's multiple range test at $P=0.05$.

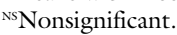

cedar shavings and $100 \mathrm{~mL}(3.4 \mathrm{fl} \mathrm{oz})$ distilled water. Treatments were replicated eight times, and all replications were stored in the same householdtype refrigerator, at a temperature of 2 ${ }^{\circ} \mathrm{C}\left(35.6^{\circ} \mathrm{F}\right) \pm 1.5^{\circ} \mathrm{C}\left(2.7^{\circ} \mathrm{F}\right)$. Scions were held in this environment for 62 to $69 \mathrm{~d}$.

To evaluate treatments in 1998, one scion was chosen randomly from each storage replication and inlay bark grafted on a 7.6 to $10.2 \mathrm{~cm} \mathrm{(3} \mathrm{to} 4$ inch) diameter limb of a 20 -year-old pecan tree in Fairhope, Ala. All 10 treatments were grafted on different limbs of one tree to eliminate variability of tree vigor, thus eight trees were involved in the study. The grafts were uniformly positioned in the upper canopy of the tree, with similar amounts of branching below the graft. All 80 grafts were done by one person. Graft success was measured 28 and $45 \mathrm{~d}$ after grafting. Fresh and dry weight was determined by air-drying the four remaining scions from the storage replications at room temperature for $45 \mathrm{~d}$ to determine moisture percentage in the scions at the time of grafting.

In 1999, the same methods were used, except that packing treatment \#1 where scions were placed directly into the refrigerator without a bag or supplemental moisture was eliminated, since all scions from that treatment were not viable in 1998. Treatment 5 was changed to a closed polyethylene bag with $50 \mathrm{~g}$ cedar shavings and 200 $\mathrm{mL}(6.8 \mathrm{fl} \mathrm{oz})$ water, rather than 100 $\mathrm{mL}$ water, in an attempt to separate the percent moisture of scions in treatments 4 and 5, which in 1998 were statistically equal. Gain or loss of fresh weight was measured at the time of grafting, and dry weight was measured of the nongrafted scions to calculate moisture percentage of the scions at grafting. All treatments of the $2 \times 4$ factorial experiment were replicated 12 times. Graft success was measured at two locations to determine whether location of grafting was a significant interaction with storage treatments. Eight replications were grafted on eight trees at Fairhope, and four replications were grafted on four trees at Uvalde, Texas, a climate with higher evaporation rates. The grafts were made by one person at each location, both having similar grafting skill.

\section{Results}

1998. Sealing the cut ends and packing material both significantly affected the moisture percentage of the scions, but only the packing material significantly affected graft success (Table 1). Scions were reduced to less than $10 \%$ moisture when not placed in a bag, even when both cut ends were sealed. Scions placed in a polyethylene bag with dry cedar shavings had less moisture than scions placed either in a bag with nothing added, or in a bag with cedar shavings plus water. Moisture percentage was not significantly different between the $1: 1$ (wt/wt) and 2:1 (wt/wt) ratio of water to cedar shavings. Sealing the cut ends only improved moisture retention of the scions when not stored in a bag. In all packing treatments where the scions were bagged, the moisture percentage was numerically higher when the ends were not sealed. Packing treatment was significant for graft success, because the unbagged scions desiccated during storage to a point that all grafts failed. Graft success was $87 \%$ or higher, and was not significantly different among the other packing treatments. 
Table 2. Effect of cut-end sealing (CES) and four packing $(P)$ treatments on weight change of pecan scions during $69 \mathrm{~d}$ of storage at $2^{\circ} \mathrm{C}\left(36^{\circ} \mathrm{F}\right)$ and moisture percentage in the scion at time of grafting in 1999.

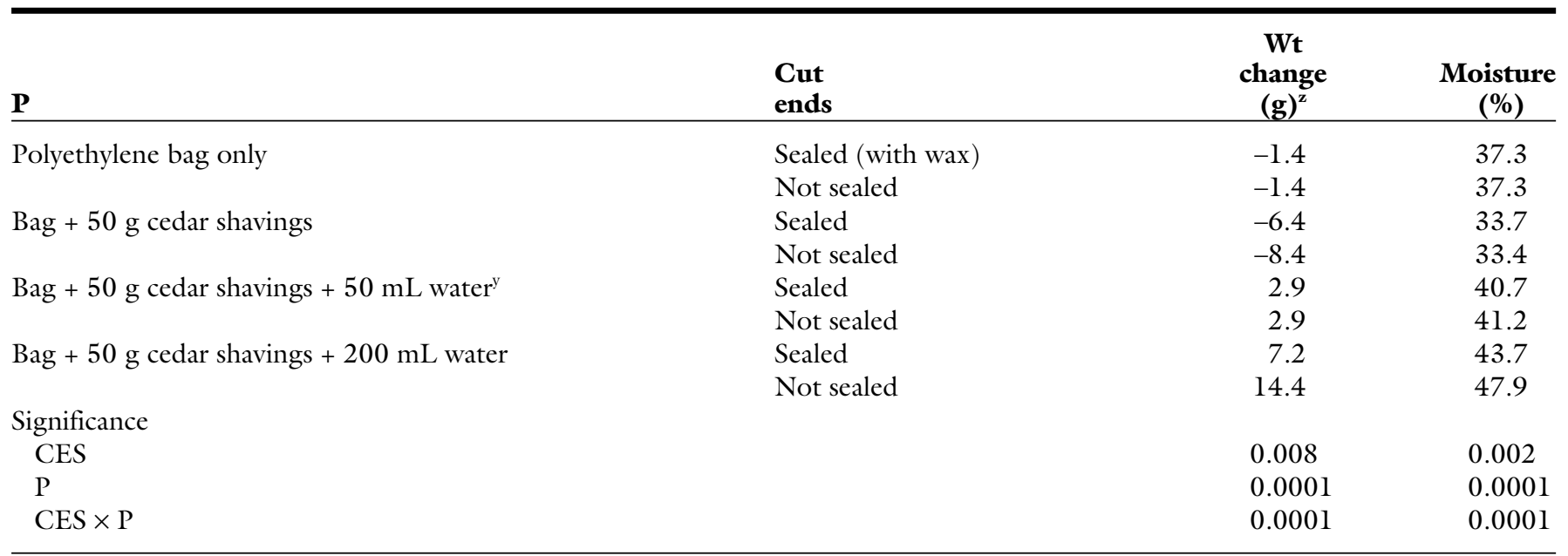

${ }^{\mathrm{z}} 1.0 \mathrm{~g}=0.035 \mathrm{oz} ; 50 \mathrm{~g}=1.8 \mathrm{oz}$.

y $50 \mathrm{~mL}=1.7 \mathrm{fl} \mathrm{oz} ; 200 \mathrm{~mL}=6.8 \mathrm{fl} \mathrm{oz}$.

Table 3. Effect of cut-end sealing (CES) and packing (P) treatments on graft success at Fairhope, Ala., and Uvalde, Texas, in 1999.

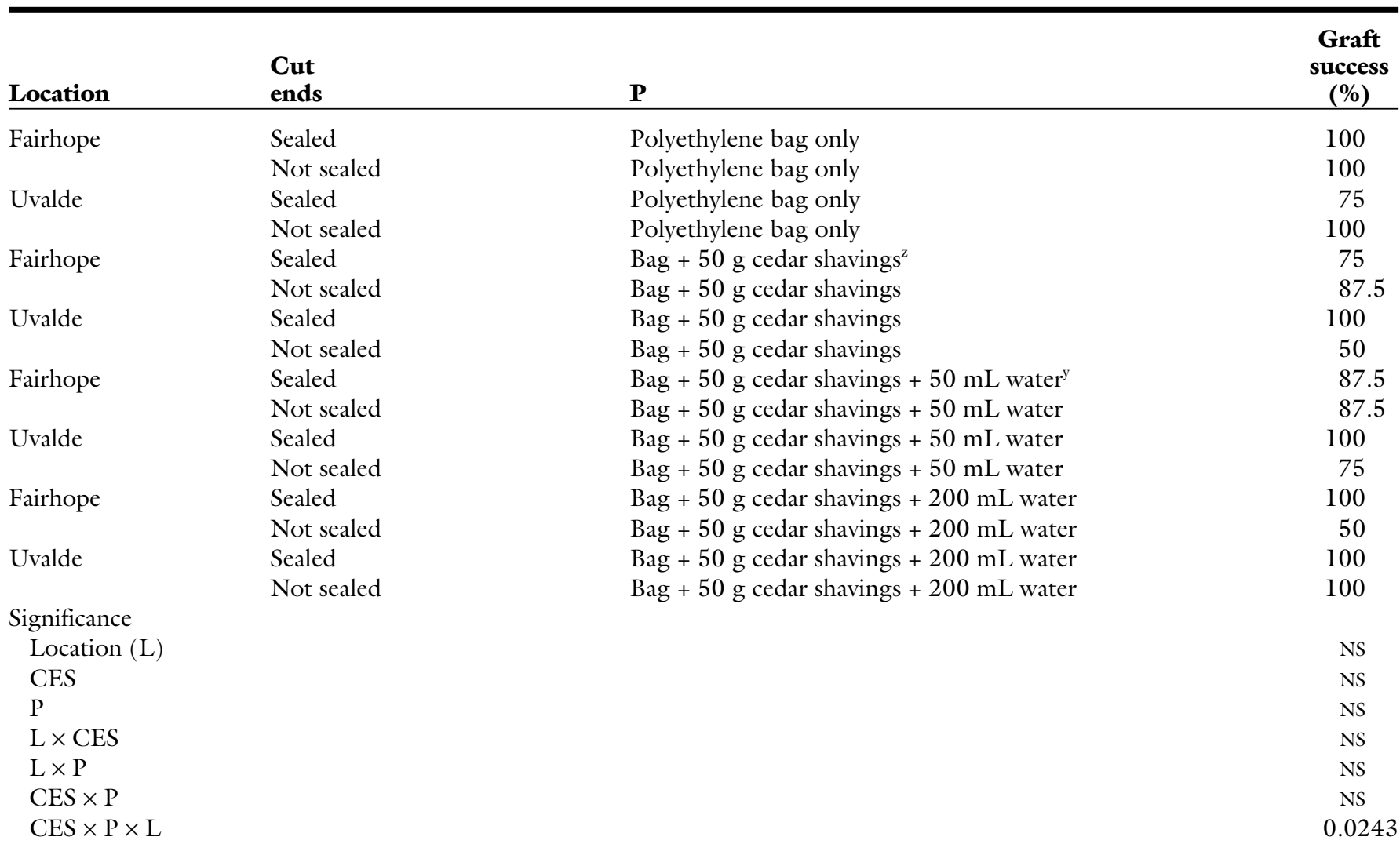

${ }^{2} 50 \mathrm{~g}=1.8 \mathrm{oz}$.

y50 $\mathrm{mL}=1.7 \mathrm{fl} \mathrm{oz} ; 200 \mathrm{~mL}=6.8 \mathrm{fl} \mathrm{oz}$.

Ns Nonsignificant.

1999. The main effects were significant again in 1999 for fresh weight change during storage and moisture percentage at the time of grafting (Table 2). However, because the unbagged treatment was eliminated in 1999 , and the 2:1 (wt/wt) water to cedar shavings treatment increased to a $4: 1$ (wt/wt) ratio, the cut-end treatment and packing treatments had a significant interaction. When pecan scions are placed in polyethylene bags with excess moisture, as with our 4:1 (wt/wt) water to cedar shavings treat- ment, they gained more moisture when the cut ends were not sealed than when the cut ends were sealed. When placed in a polyethylene bag with dry cedar shavings, scions lost more moisture when the ends were not sealed. Thus, the cut ends are a site for signifi- 
cant moisture loss or gain during storage, depending on the amount of supplemental moisture in the packing material. Moisture percentage was equal to or numerically higher when the cut ends were not sealed than when sealed in both years. This finding contradicts a common belief that scions with the cut ends sealed will have higher moisture content than those that do not.

Graft success was not significantly affected by either main effect alone or their interactions in 1999 (Table 3); however, there was a significant interaction of location, cut-end sealing, and packing treatment. At Uvalde, graft success was only $50 \%$ when the ends were not sealed and the packing material was dry cedar shavings. Scions of this treatment also had the lowest percent moisture (33.4\%). Mean daily temperatures and Class A pan evaporation rates were higher at Uvalde than Fairhope on most of the $21 \mathrm{~d}$ after grafting. Rainfall during the period was $2.5 \mathrm{~cm}$ ( 1.0 inch) at Fairhope and $7.6 \mathrm{~cm}$ (3.0 inches) at Uvalde, but the number of days with precipitation was three at Fairhope and only one at Uvalde.

At Fairhope, graft success was only $50 \%$ when the ends were not sealed and the packing material was very wet (4 water : I cedar shavings), which caused scions to have the highest moisture percentage $(48 \%)$. The buds of the 4 water : 1 cedar shavings treatment were noted to be swollen in 1999 compared to other treatments, and in some case mold growth was evident growing in the cedar shavings and on the surface of the scions themselves. Experienced pecan propagators avoid grafting with scions that have swollen buds, because of the belief that swollen buds may commence growth before a callus bridge has formed. Mold growth on scions caused by the wet storage conditions is also known to reduce graft success (Banta, 1967; Hartmann et al, 1990). Because the buds were pre-exposed to mold growth in storage, grafting the scions in a hot humid climate like Fairhope may have resulted in further damage by fungi and a lower graft success rate.

\section{Discussion}

Water can be lost from any surface of the plant that is not entirely waterproofed (Ting, 1982). Possible sites of a pecan scion that are not waterproof, apart from the cut ends, include leaf scars, lenticels, and bud scales; however, the potential of these structures to transpire water at low temperatures has not been studied on pecan. Depending on the arrangement of the cells of lenticels, water loss through them can be rather significant (Ting, 1982). Thus the finite percentage of moisture in a cut stem would decrease over time if placed in a dry atmosphere that formed a water loss gradient. The drastic moisture loss of scions not placed in bags in 1998 confirms that water loss through sites other than the cut ends can be dramatic under the right humidity conditions. Sauls and Crocker (1979) described that many nurserymen in Florida waxed the entire graft stick to prevent moisture loss in the field during grafting. While such efforts would indeed prevent all water loss from the scion, our results indicate that good graft success can be obtained without any use of wax on the cut ends or elsewhere. Polyethylene bags have high moisture retention, and when polyethylene bags are used, no additional moist packing material is needed, because the natural moisture in the wood is sufficient and little will be lost (Hartmann et al., 1990).

In our tests over 2 years, scions placed directly in a polyethylene bag with no packing material had more moisture loss than when damp or wet packing material was added, but graft success was equal to or better than those with moist packing, depending on the location of grafting and cut-end sealing treatment. Sealing the cut ends is only an advantage to graft success if the scion is going to be placed in a storage environment that is very wet or very dry. Water loss of the scion during storage may affect graft success in a climate with high evaporation rates. With certain moisture and packing treatments, sealing the cut ends actually results in a lower moisture percentage of the scion than if the ends are not sealed. Perhaps when large quantities of wood are being prepared for storage, the sealing of cut ends retards moisture loss before placement in a polyethylene bag or waxed box. The sealing process though, increases the preparation time and preparation cost of the scionwood, which appears to be unnecessary for pecan scions placed in closed polyethylene bag with either no supplemental moisture or slightly moist packing material.

\section{Literature cited}

Banta, E.S. 1967. Fruit tree propagation. Ohio State Coop. Ext. Serv. Bul. 481.

Hartmann, H.T., D.E. Kester, and F.T. Davies. 1990. Plant propagation. $5^{\text {th }}$ ed. Prentice-Hall, Englewood Cliffs, N.J.

McEachern, G.R. and L.A. Stein. 1997. Collecting and storing graftwood, p. XI7-XI-8. In: G.R. McEachern and L.A. Stein (eds.). Texas pecan handbook. Texas Agr. Ext. Serv. HORT Hndbk. 105.

Morris, R.T. 1921. Nut growing. Publisher unknown, New York.

Mullenax, R. 1983. Pecan production: Grafting pecan trees. Miss. Coop. Ext. Serv. Info. Sheet 530.

Reed, C.A. 1926. Nut-tree propagation. USDA Farmers' Bul. 1501.

Sauls, J.W. and T.E. Crocker. 1979. Nursery propagation of pecan trees. Fla. Coop. Ext. Serv. FC-56.

Taylor, W.A. 1905. Promising new fruit, Pecans, p. 405-416. In: G.W. Hill (ed.). Yearbook of the USDA, 1904. U.S. Gov. Print. Office, Wash. D.C.

Ting, I.P. 1982. Plant physiology. AddisonWesley, Reading, Mass. 